\title{
Penerapan Model Pembelajaran ATI (Aptitude Treatment Interaction) untuk Meningkatkan Keaktifan Belajar IPA
}

\section{Ni Putu Suastini*

\author{
A R T I C L E I N F O \\ Article history: \\ Received 19 May 2018 \\ Received in revised form \\ 25 June 2018 \\ Accepted 10 July 2018 \\ Available online 25 \\ August 2018 \\ Kata Kunci: \\ keaktifan belajar IPA, \\ ATI (Aptitude Treatment \\ Interaction) \\ Keywords: \\ science learning \\ participation, $A T I$ \\ (Aptitude Treatment \\ Interaction).
}

\begin{abstract}
A B S T R A K
Tujuan dari penelitian ini adalah untuk mengetahui peningkatan keaktifan belajar IPA pada siswa kelas IV SD N 3 Sibang Kaja semester I tahun pelajaran 2016/2017 setelah diterapkannya model pembelajaran ATI (Aptitude Treatment Interaction). Jenis penelitian ini adalah penelitian tindakan kelas (PTK) dengan subjek penelitian siswa kelas IV SD N 3 Sibang Kaja semester I tahun pelajaran 2016/2017 sebanyak 20 orang siswa. Data keaktifan belajar dikumpulkan dengan lembar observasi. Data yang diperoleh dianalisis menggunakan analisis statistik deskriptif. Berdasarkan hasil penelitian yang telah dilakukan dapat disimpulkan bahwa: penerapan model pembelajaran Aptitude Treatment Interaction (ATI) dapat meningkatkan keaktifan belajar IPA pada siswa kelas IV SD N 3 Sibang Kaja semester I tahun pelajaran 2016/2017. Hasil ini terbukti dari peningkatan rata-rata siklus I sebesar 15,35 menjadi 21,30 pada siklus II. Ketuntasan klasikal siswa pun mengalami peningkatan dari $55 \%$ pada siklus I menjadi 95\% pada siklus II.
\end{abstract}

\section{A B S T R A C T}

The purpose of this study was to determine the improvement of science learning participation of fourth grade students of SD N 3 Sibang Kaja in the first semester of the academic year 2016/2017 after the implementation of the ATI learning model (Aptitude Treatment Interaction). The type of this research was classroom action research (CAR). The research subjects were 20 students of the fourth grade students. The learning participation data was collected by observation sheet. The data obtained were analyzed using descriptive statistical analysis. Based on the results of the research that has been done, it can be concluded that the application of the Aptitude Treatment Interaction (ATI) learning model can increase the students' learning participation in science. This can be seen from the improvement of the average score. In the first cycle the average score of the students was 15.35 and it was become 21.30 in the second cycle. The classical completeness of students also increased from $55 \%$ in the first cycle to $95 \%$ in the second cycle. 


\section{Pendahuluan}

Pendidikan pada dasarnya bertujuan untuk membentuk karakter peserta didik. Tujuan yang diharapkan dalam pendidikan tertuang dalam Undang undang Nomor 20 Tahun 2003 tentang Sistem Pendidikan Nasional dalam pasal 3 yang isinya adalah Pendidikan nasional berfungsi mengembangkan dan membentuk watak serta peradaban bangsa yang bermartabat dalam rangka mencerdaskan kehidupan bangsa, bertujuan untuk berkembangnya potensi peserta didik agar menjadi manusia yang beriman dan bertakwa kepada Tuhan Yang Maha Esa, berakhlak mulia, sehat, berilmu, cakap, kreatif, mandiri, dan menjadi warga negara yang demokratis serta bertanggung jawab.

Pendidikan menjadi komponen dasar yang harus dikembangkan oleh setiap bangsa agar mampu menyiapkan SDM yang berkualitas. Namun mutu pendidikan di Indonesia tergolong masih rendah, hal ini dapat dilihat dari mutu pendidikan yang ada di Indonesia yang masih belum merata dimana pendidikan yang ada di daerah pedesaan masih kurang jika dibandingkan dengan daerah perkotaan. Untuk meningkatkan mutu pendidikan yang baik dan berkualitas, maka perlu adanya pembenahan-pembenahan yang dapat meningkatkan mutu pendidikan seperti menyiapkan tenaga pendidik yang profesional.

Masalah utama dalam pembelajaran pada pendidikan formal (sekolah) adalah rendahnya daya serap peserta didik (Trianto, 2009: 5). Permasalahan ini juga terjadi di kelas IV SD No 3 Sibang Kaja tahun pelajaran 2016/2017. Rendahnya daya serap peserta didik terutama dalam pembelajaran Ilmu Pengetahuan Alam (IPA) yang merupakan mata pelajaran pokok yang ada adalam pembelajaran di Sekolah Dasar (SD). IPA adalah ilmu pengetahuan yang mempelajari tentang alam dan gejala-gejala alam dan erat kaitanya dengan kehidupan sehari-hari siswa, dimana dalam pembelajaran IPA siswa akan mempelajari tentang lingkungan yang ada di sekitar mereka dan cara mereka berinteraksi dengan lingkungan.

Namun dalam pembelajaran IPA seringkali siswa kurang mengerti dan kurang tertarik terhadap materi yang telah disampaikan. Hal ini dikarenakan guru lebih mendominasi pembelajaran dan kurang memberi kesempatan kepada siswa untuk mengembangkan ide ataupun pemahaman mereka terhadap materi yang disampaiakan. Dengan demikian maka guru harus memilih model pembelajaran yang sesuai dengan kondisi siswa, karena model membelajaran yang diberikan sangat menentukan tingkat pemahaman siswa.

Permasalahan-permasalahan yang menjadi faktor kurangnya pemahaman siswa terhadap materi pelajaran IPA, yaitu 1) rendahnya keaktifan siswa terhadap pelajaran IPA, hal ini disebabkan karena siswa tidak mengetahui seberapa pentingnya pelajaran IPA tersebut, 2) pemahaman guru terhadap modelmodel pembelajaran masih kurang, dan 3) pembelajaran yang dilakukan kurang optimal karena model pembelajaran masih bersifat konvensional, padahal untuk pelajaran IPA siswa hendaknya terlibat secara aktif sehingga siswa mampu mengembangkan ide dan pemahamanya terhadap pelajaran IPA.

Upaya yang dapat dilakukan untuk mengatasi permasalahan di atas, adalah dengan menerapkan model pembelajaran ATI (Aptitude Treatment Interaction). Secara substantif dan teoritik "Aptitude Treatment Interaction (ATI)" dapat diartikan sebagai suatu konsep/pendekatan yang memiliki sejumlah strategi pembelajaran yang efektif digunakan untuk individu tertentu sesuai dengan kemampuannya masing-masing (Nurdin, 2005: xiv). Hal ini berarti, dipandang dari sudut pandang (teoretis), model ATI merupakan sebuah konsep (model) yang berisikan sejumlah strategi pembelajaran yang efektif digunakan untuk siswa tertentu sesuai dengan karakteristik kemampuannya. Hal ini didasari oleh asumsi bahwa optimalisasi prestasi akademik/hasil belajar dapat dicapai melalui penyesuaian antara pembelajaran dengan perbedaan kemampuan siswa. Model pembelajaran ATI adalah suatu model pembelajaran yang berisikan sejumlah perlakuan/treatment tertentu yang efektif digunakan untuk siswa sesuai dengan level kemampuan masing - masing siswa (Saregar, 2017). Model pembelajaran ini membagi kelompok belajar berdasarkan kemampuan yang dimiliki siswa dan dalam setiap kelompok kemampuan diberi sebuah treatment (perlakuan) yang berbeda (Mayasari, 2014).

Berdasarkan pemaparan di atas, maka pada penelitian ini akan mengambil judul tentang penerapan model pembelajaran ATI (Aptitude Treatment Interaction) untuk meningkatkan keaktifan belajar IPA pada siswa kelas IV SD No 3 Sibang Kaja semester I tahun pelajaran 2016/2017.

Tujuan dari penelitian ini adalah untuk mengetahui peningkatan keaktifan belajar IPA pada siswa kelas IV SD No 3 Sibang Kaja semester I tahun pelajaran 2016/2017 setelah diterapkannya model pembelajaran ATI (Aptitude Treatment Interaction).

\section{Metode}

Penelitian dilaksanakan pada Semester I tahun pelajaran 2016/2017 di SD No 3 Sibang Kaja. Penelitian dilakukan selama empat bulan dari bulan Agustus sampai dengan bulan November 2016. 
Dalam penelitian ini yang menjadi subjek penelitian adalah siswa kelas IV Semester 1 tahun pelajaran 2016/2017 di SD No 3 Sibang Kaja sebanyak 20 orang. Objek dalam penelitian tindakan kelas ini yaitu keaktifan belajar siswa melalui penerapan model pembelajaran ATI.

Penelitian ini dirancang dengan menggunakan Penelitian Tindakan Kelas (PTK). Penelitian ini merupakan PTK karena penelitian ini dilakukan untuk memecahkan masalah pembelajaran di kelas. Penelitian juga termasuk penelitian deskriptif, sebab menggambarkan penerapan suatu pembelajaran untuk meningkatkan minat belajar siswa. Penelitian ini dilaksanakan dalam sistem siklus. Tiap siklus terdiri atas empat tahapan yaitu: tahap perencanaan, tahap tindakan, tahap observasi/evaluasi, dan tahap refleksi (Agung, 2005). Dalam penelitian tindakan kelas (PTK) ini mengacu pada teori yang dikemukakan Kemmis dan Mc Taggrat (Agung, 2005:91). Seperti gambar di bawah ini.

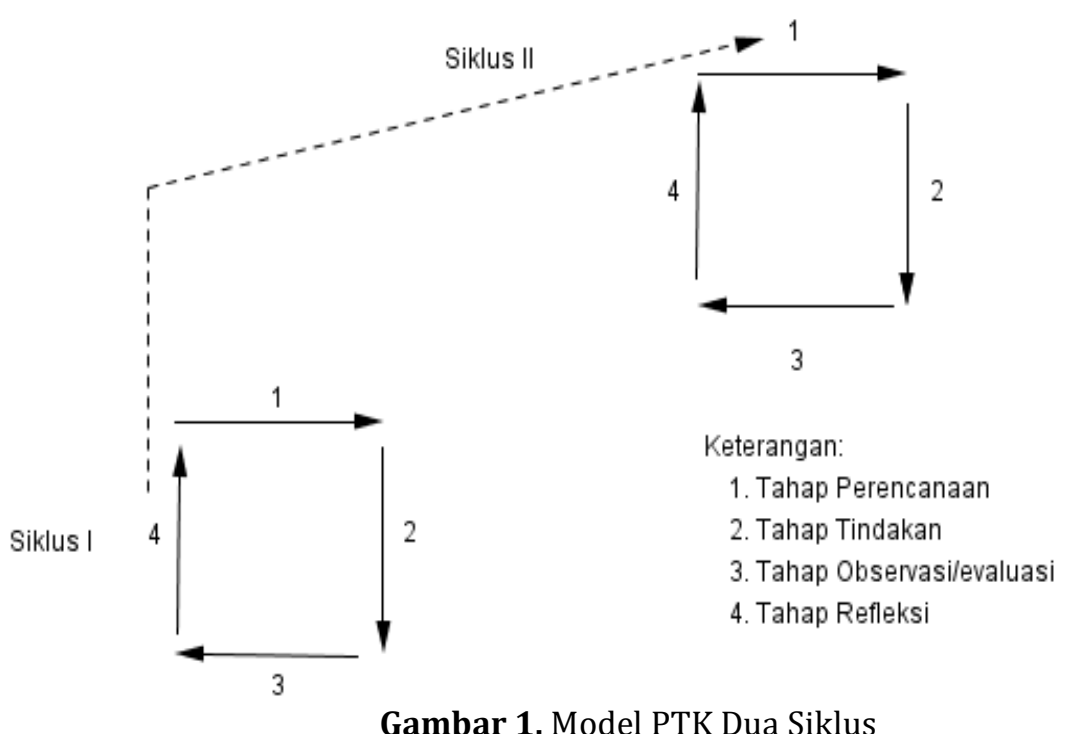

Penelitian ini direncanakan dalam beberapa siklus, tiap siklus terdiri dari empat tahapan yaitu perencanaan, pelaksanaan, observasi, dan refleksi. Jika sudah memenuhi hasil yang diharapkan maka siklus tidak dilanjutkan lagi. Adapun rancangan penelitian tindakan kelas yang dilakukan terdiri dari dua siklus yaitu sebagai berikut.

1. Rancangan Penelitian Tindakan Kelas Siklus I

Siklus I dilakukan dalam tiga (3) kali pertemuan.

a. Rencana tindakan

Berdasarkan pengalaman yang peneliti selama mengajar di kelas IV SD No 3 Sibang Kaja, maka dirancang suatu model pembelajaran yaitu model pembelajaran ATI. Agar model pembelajaran tersebut dapat diterapkan dengan baik dan sesuai dengan tujuan penelitian yang dirumuskan, ada beberapa hal yang perlu dipersiapkan oleh guru mata pelajaran matematika, yaitu sebagai berikut.

1. Mengkaji silabus

2. Menyiapkan materi yang dikaji sesuai dengan silabus.

3. Menyusun rencana pembelajaran sebagai pedoman untuk melaksanakan pembelajaran.

4. Menyiapkan instrument untuk mengumpulkan data yang diperlukan seperti lembar observasi yang digunakan untuk mengetahui keaktifan belajar siswa.

b. Pelaksanaan tindakan

Pada siklus I ini, tindakan dilakukan tiga (3) x pertemuan sesuai dengan perencanaan yang telah dibuat sebelumnya, dimana masing-masing pertemuan diatur dalam rencana pelaksanaan pembelajaran (RPP).

c. Pemantauan/observasi dan Evaluasi

Pemantauan/observasi dilakukan pada saat pelaksanaan tindakan yang meliputi hal-hal yang berkaitan pelaksanaan tindakan menggunakan lembar pengamatan/observasi.

d. Refleksi

Refleksi diberikan untuk melihat sejauh mana penguasaan konsep dan prestasi belajar siswa pada siklus I. Berdasarkan hasil refleksi ini digunakan sebagai dasar untuk memperbaiki dan menyempurnakan perencanaan dan pelaksanaan tindakan pada siklus I serta mencari cara untuk memecahkan masalah yang ada, yang selanjutnya akan dirumuskan untuk pelaksanaan siklus selanjutnya. 
2. Rancangan Penelitian Tindakan Kelas Siklus II

Pada siklus II, dilaksanakan dengan memperhatikan hasil evaluasi pada siklus I dengan memperbaiki cara mengajar dan kelengkapan media. Tahap penelitian siklus II juga sama seperti siklus I. Untuk mengumpulkan data dalam penelitian ini menggunakan metode observasi. Metode observasi berguna untuk melakukan pengamatan tentang keaktifan siswa dalam mengikuti proses pembelajaran siswa. Untuk memperjelas uraian tentang variabel, metode dan alat pengumpul data serta sumber dan sifat data, dapat disajikan seperti matrik sebagai berikut.

Tabel 1. Variabel, Metode, Instrumen, Sumber Dan Waktu Kegiatan

\begin{tabular}{|l|l|l|l|l|l|}
\hline No & $\begin{array}{c}\text { Aspek yang } \\
\text { diamati/variabel }\end{array}$ & Metode & $\begin{array}{c}\text { Sumber } \\
\text { data }\end{array}$ & Instrument penelitian & Waktu kegiatan \\
\hline 1 & Keaktifan belajar & Observasi & Siswa & Lembar obsevasi & $\begin{array}{l}\text { Dilaksanakan pada } \\
\text { proses } \\
\text { pembelajaran }\end{array}$ \\
\hline
\end{tabular}

Setelah data dalam penelitian ini terkumpul selanjutnya dilakukan analisis data. Dalam menganalisis data digunakan teknik analisis statistik deskriptif kuantitatif. Agung (2011) mengemukakan metode analisis deskriptif kuantitatif merupakan pengolahan data yang dilakukan dengan jalan penyusunan secara sistematis dalam bentuk angka-angka dan atau persentase mengenai keadaan suatu objek yang diteliti sehingga diperoleh kesimpulan umum. Untuk menghitung nilai rata-rata (Mean) digunakan rumus sebagai berikut.

$$
M(\%)=\left[\frac{M}{S M I}\right] \times 100 \% \quad \text { (Agung, 2011:32) }
$$

Keterangan :

$$
\begin{array}{ll}
\mathrm{M}(\%) & =\text { Rata-rata persen } \\
\mathrm{M} & =\text { Rata-rata skor } \\
\mathrm{SMI} & =\text { Skor Maksimal Ideal }
\end{array}
$$

Tingkatan keaktifan belajar pada mata pelajaran IPA siswa dapat ditentukan dengan membandingkan M (\%) atau rata-rata persen ke dalam PAP skala lima dengan kriteria sebagai berikut.

Tabel 2. Pedoman Konversi Skala Lima

\begin{tabular}{|c|l|c|}
\hline NO & SKALA & KLASIFIKASI \\
\hline 1. & $\mathrm{X} \geq \mathrm{Mi}+1,5 \mathrm{SDi}$ & sangat tinggi \\
\hline 2. & $\mathrm{Mi}+1,5 \mathrm{SDi}>\mathrm{X} \geq \mathrm{Mi}+0,5 \mathrm{SDi}$ & tinggi \\
\hline 3. & $\mathrm{Mi}+0,5 \mathrm{SDi}>\mathrm{X} \geq \mathrm{Mi}-0,5 \mathrm{SDi}$ & rendang \\
\hline 4. & $\mathrm{Mi}-0,5 \mathrm{SDi}>\mathrm{X} \geq \mathrm{Mi}-1,5 \mathrm{SDi}$ & sangat rendah \\
\hline 5. & $\mathrm{X}<\mathrm{Mi}-1,5 \mathrm{SDi}$ & \\
\hline
\end{tabular}

Keterangan :

$\mathrm{Mi} \quad=1 / 2($ skor maksimum + skor minimum $)$

SDi $\quad=1 / 6$ (skor maksimum - skor minimum)

Indikator keberhasilan pelaksanaan ini, berpedoman pada beberapa kriteria sebagai berikut. Tingkat keaktifan belajar IPA siswa minimal memenuhi kategori Tinggi. Keberhasilan siswa secara klasikal bila mencapai ketuntasan belajar $90 \%$. 


\section{Hasil dan Pembahasan}

Pembelajaran pada siklus I, sudah berlangsung dengan cukup baik, terlihat siswa yang awalnya kurang aktif dalam pembelajaran, sudah mulai aktif dalam kegiatan pembelajaran baik secara berkelompok maupun individual, siswa sudah lebih berani mengemukakan pendapat dan memberikan jawaban atas pertanyaan teman atau gurunya.

Kendala yang dihadapi pada siklus I adalah ada beberapa siswa yang memiliki kemampuan rendah agak sulit mengikuti pembelajaran karena kurang berkonsentrasi dan agak lama menerima atau memahami penjelasan dari teman atau gurunya. Disini peran guru harus lebih diintensifkan untuk sabar memberikan penjelasan dan pemahaman kepada siswa agar lebih cepat memahami apa yang dipelajarinya.

Berdasarkan pemaparan di atas, pada siklus I rerata keaktifan belajar siswa $=15,35$ yang dikonvesikan ke dalam PAP skala lima, berada pada tingkat penguasaan $17>\mathrm{X} \geq 13$ yang berarti bahwa tingkat keaktifan belajar IPA siswa siklus I tergolong sedang. Ketuntasan klasikalnya $=55 \%$, karena ada beberapa siswa yang memiliki keaktifan belajar di bawah katagori tinggi.

Berdasarkan pemaparan di atas, kategori keaktifan belajar siswa berada pada kategori sedang dan ketuntasan siswa tidak mencapai $90 \%$ sehingga belum mencapai kategori dan ketuntasan yang ditetapkan oleh peneliti, yakni kategori keaktifan belajar siswa berada pada kategori minimal tinggi dan dan ketuntasan klasikal 90\%. Sehingga dapat disimpulkan bahwa siklus I belum berhasil dan harus diadakan siklus II dengan memperhatikan kendala-kendala yang dihadapi siklus I.

Kegiatan pembelajaran siklus II sudah berjalan lebih baik lagi dari pembelajaran siklus I. Hal ini disebabkan karena kegiatan tutor sebaya dan perhatian guru terhadap siswa yang memiliki kemampuan yang kurang lebih banyak, sehingga siswa termotivasi dan merasa diperhatikan oleh teman maupun gurunya.

Berdasarkan pemaparan di atas, pada siklus II rerata keaktifan belajar siswa $=21,30$ yang dikonvesikan ke dalam PAP skala lima, berada pada tingkat penguasaan $X \geq 20$ yang berarti bahwa tingkat keaktifan belajar IPA siswa siklus II tergolong tinggi. Ketuntasan klasikalnya $=95 \%$, masih ada 1 orang siswa yang memiliki keaktifan belajar sedang.

Hal ini menunjukkan bahwa kendala-kendala yang dihadapi pada siklus I sudah dapat diatasi pada siklus II. Maka dari itu kriteria ketuntasan minimal baik dan ketuntasan klasikal 90\% sudah terpenuhi sehingga penelitian pada siklus II dinyatakan berhasil dan siklus dihentikan. berikut.

Secara statistik, peningkatan keaktifan siswa dari siklus I ke siklus II dapat dilihat pada tabel

Tabel 3. Peningkatan Keaktifan Siswa dari Siklus I ke Siklus II

\begin{tabular}{lcc}
\hline \multicolumn{1}{c}{ Statistik } & Siklus I & Siklus II \\
\hline Rata-rata & 15,35 & 21,3 \\
Nilai Tengah & 17 & 21,5 \\
Nilai yang paling sering muncul & 18 & 23 \\
Nilai maksimum & 19 & 25 \\
Nilai Minimum & 10 & 16 \\
Ketuntasan Klasikal & $55 \%$ & $95 \%$ \\
\hline
\end{tabular}

Apabila digambarkan, peningkatan keaktifan siswa dari siklus I ke siklus II dapat dilihat pada gambar berikut.

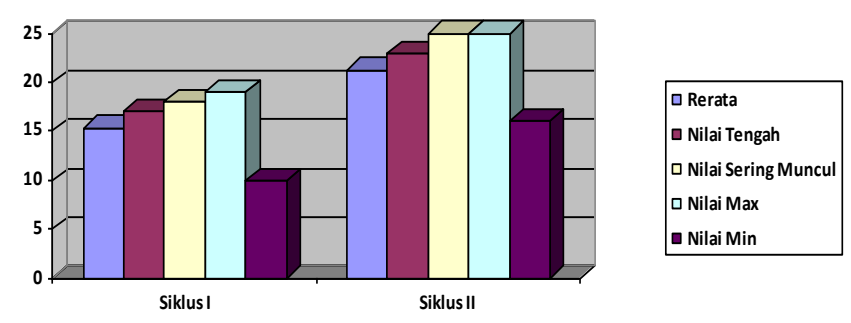

Gambar 1 Peningkatan Keaktifan Siswa dari Siklus I ke Siklus II 
Hasil penelitian ini sejalan dengan hasil penelitian yang dilakukan oleh Windari (2011) dengan judul penerapan model pembelajaran Aptitude Treatment Interaction (ATI) berbantuan Hand Out untuk meningkatkan pemahaman konsep Matematika siswa kelas X3 SMA Negeri 4 Singaraja" menyatakan mengalami peningkatan dari siklus ke siklus dan besarnya sampai 84,69. Sehingga dapat disimpulkan bahwa penerapan model pembelajaran Aptitude Treatment Interaction (ATI) berbantuan Hand Out dapat meningkatkan pemahaman konsep Matematika siswa kelas X3 SMA Negeri 4 Singaraja dengan optimal.

\section{Simpulan Dan Saran}

Berdasarkan penelitian yang telah dilakukan, dapat disimpulkan penerapan model pembelajaran Aptitude Treatment Interaction (ATI) dapat meningkatkan keaktifan belajar IPA pada siswa kelas IV SD No 3 Sibang Kaja semester I tahun pelajaran 2016/2017. Hasil ini terbukti dari peningkatan rata-rata siklus I sebesar 15,35 menjadi 21,30 pada siklus II. Ketuntasan klasikal siswa pun mengalami peningkatan dari $55 \%$ pada siklus I menjadi $95 \%$ pada siklus II.

Dari simpulan penelitian di atas, adapun saran yang dapat diajukan pada penelitian ini adalah sebagai berikut. (1) Siswa disarankan agar bersemangat dan berkonsentrasi dalam belajar, sehingga keaktifan siswa dapat ditingkatkan dan mudah memahami materi pembelajaran yang diberikan guru. (2) Guru disarankan agar mengajar tidak monoton menggunakan model pembelajaran, sehingga siswa tidak merasa jenuh dalam mengikuti proses pembelajaran. (3) Kepala sekolah disarankan untuk selalu mendukung proses pembelajaran dengan mengambil kebijakan-kebijakan yang bertujuan untuk meningkatkan sumber daya manusia di sekolah. (4) Peneliti lain disarankan untuk mengembangkan penelitian ini sehingga permasalahan dalam dunia pendidikan dapat diatasi dengan optimal.

\section{Daftar Rujukan}

Agung, A. A. G. 2005. Metodologi Penelitian Pendidikan: Suatu Pengantar. Singaraja: IKIP Negeri Singaraja.

Agung, A. A. G. 2011. Metodologi Penelitian Pendidikan. Singaraja: Undiksha.

Agustini. D, I W. Subagia, dan I N. Suardana. 2013. "Pengaruh Model Pembelajaran Sains Teknologi Masyarakat (STM) Terhadap Penguasaan Materi Dan Keterampilan Pemecahan Masalah Siswa Pada Mata Pelajaran IPA Di MTS. Negeri Patas". e-Journal Program Pascasarjana Universitas Pendidikan Ganesha. Volume 3.

Artini, Eka. 2013. "Pengaruh Model Pembelajaran Kooperatif Tipe Numbered Head Together (NHT) Berbasis Proyek Terhadap Hasil Belajar IPA Siswa Kelas V SD Gugus IV Kerobokan Kelod Tahun Ajaran 2013/2014". Jurusan Pendidikan Guru Sekolah Dasar, Universitas Pendidikan Ganesha.

Erniati, U, W., \& Nurjannah. (2014). Perbandingan Hasil Belajar Fisika Antara Model pembelajaran Aptitude Treatment Interaction (ATI) Dengan Model Pembelajaran Student Teams Achievment Division(Stad) Pada Siswa Kelas X SMA Negeri 1 Ampana Kota. Jurnal Pendidikan Fisika Tadulako (JPFT). Vol. 2, No.1.

Mayasari, Asputri dan Kusrini. 2014. Penerapan Model Pembelajaran Aptitude Treatment Interaction Pada Siswa Kelas VIII-F Smp Negeri 6 Madiun Dalam Materi Faktorisasi Aljabar. Jurnal Ilmiah Pendidikan Matematika. Vol. 3, No. 1.

Nurdin, S.2005. Model Pembelajaran yang Memperhatikan Keragaman Individu dalam Kurikulum Berbasis Kompetensi (KBK). Jakarata: Quantum Teaching.

Putra, A. N., Renda, N. T., \& H, S. (2014). Pengaruh Model Pembelajaran ATI (Aptitude Treatment Interaction) Berbantuan Peta Konsep Terhadap Hasil Belajar IPA. Journal Mimbar PGSD Universitas Pendidikan Ganesha Jurusan PGSD. Vol. 2 No. 1.

Saregar, Antomi, Rahma Diani, dan Ridho Kholid. 2017. Efektivitas Penerapan Model Pembelajaran ATI (Aptitude Treatment Interaction) Dan Model Pembelajaran TAI (Team Assisted Individualy): Dampak Terhadap Hasil Belajar Fisika Siswa. Jurnal Pendidikan Fisika dan Keilmuan. Vol. 3, No. 1. 
Setiawan, Putu Zulvi dan Efendi Napitupulu. 2014. Aplikasi Media Pembelajaran Flipchart Untuk Meningkatkan Penguasaan Materi Pertumbuhan Dan Perkembangan Pada Mata Pelajaran IPA Terpadu. Jurnal Teknologi Pendidikan. Vol 7, No. 2.

Suwandi, Y. (2015). Peningkatan Hasil Belajar IPA Tentang Ekosistem Melalui Metode Problem Based Learning Pada Siswa Kelas V Sekolah Dasar Kabupaten Tana Tidung. Jurnal Pendidikan Dasar Volume 6 Edisis 1 Mei 2015, 93 - 102.

Trianto. 2009. Mendesain Model Pembelajaran Inovatif-Progresif. Surabaya: Prenada Media Group.

Wardani, N. C., Suwatra, I. W., \& Wirya, N. (2014). Pengaruh Model Pembelajaran Team Assisted Individualization (TAI) Terhadap Hasil Belajar Mata Pelajaran IPA Pada Siswa Kelas VII Tahun Ajaran 2014/2015 Di SMP Negeri 1 Banjar. Jurnal Edutech, Vol. 2 No. 1.

Windari, Dian. 2011. Penerapan Model Pembelajarn Aptitude Treatment Interaction (ATI) Berbantuan Hand Out untuk Meningkatkan Pemahaman Konsep Matematika Siswa Kelas X3 SMA Negeri 4 Singaraja. Skripsi (tidak diterbitkan). Singaraja: Universitas Pendidikan Ganesha. 